\title{
Kirk Palmer
}

Faculty of Philology

University of Bialystok

\section{Early American Stage Hits: Spinning Gold from Chaff}

Nineteenth century America spawned world-class novelists: Herman Melville, Mark Twain - poets: Walt Whitman, Emily Dickinson - and essayist/philosophers: Ralph Waldo Emerson, Henry David Thoreau. But in the field of drama, no memorable or even noteworthy name can be put forward. No early dramatic work endures as part of 'the canon,' even of American literature. None of the plays are taught in high-school; rarely do they appear on university reading lists. Royall Tyler's The Contrast (1787) is occasionally anthologized, by virtue of being the first post-Constitution native-authored drama. Even André (1798) - the most critically regarded work by "the Father of the American Drama" ${ }^{1}$ William Dunlap - seldom appears in any venue but esoteric collections of early American drama. Beyond the above named playwrights, it is difficult to find works by any of their contemporaries still in print, though the Internet has opened a door for more of them to have some public access.

But to accept that these mostly awful works were indeed of poor literary quality is not to say that these native dramas were not successful. Certain works were bona-fide financial hits: Anna Cora Mowatt's Fashion, George Aiken's "pirate" version of Uncle Tom's Cabin (the most successful of the dozen or more spin-offs of Harriet Beecher Stowe's landmark book), and a handful of star-driven vehicles like Rip Van Winkle or Metamora: the Last of the Wamponoags, written specifically for their super-stars, Joseph Jefferson and Edwin Forrest, respectively. Long forgotten works like Clari, the Maid of Milan contributed the enduringly popular and sentimental song "Home, Sweet Home" - now traditionally in the American song canon, learned by all elementary school children. (Its final line "There's no place like home" is also the closing sentence intoned by a teary-eyed Judy Garland in The Wizard of Oz.) Financial and popular success, however, are

1 Montrose J. Moses, The American Dramatist, Boston 1911, p. 60. 
only part of the story. For in many ways, these works successfully molded Americans' attitudes about their national character while also promulgating a rock solid sense of patriotism necessary in a new-formed nation.

American plays of every category - Comedies of Manners, Historical, melodramas (a category that includes virtually all of the works), Tragedies - all suffered from a fatal combination of features ensuring their mediocrity. The nearblood ties with England had brought with them not only the ancient traditions of the stage (with all the greater and lesser elements thus entailed), but also a puritanical tradition that both condemned theater itself as an art-form and condoned the writing and/or re-writing of plots and passages to attain specific moral ends with little regard for aesthetics. As David Grimsted underlines in his classic study Melodrama Revisited "No melodramatic [work] broke with this tradition."2

150 years before the birth of American drama, John Milton argued that "the Apostle Paul himself thought it not unworthy to insert a verse of Euripides into the text of Holy Scripture, I Cor, xv. 33" in response to the growing calls in England to close all theaters. For the poet and others, proper moral instruction of the masses should derive from whatever source possible. But America's Puritans were hardly convinced: Increase and Cotton Mather warned different generations of the "devil's library" - i.e. plays. (Robinson Crusoe, the first novel in English, published in 1719, would hardly have been on their radar.) As had happened earlier in England, theaters in the colonies were closed after October 20, 1774 when fear of the potential for corruption offered by the theater (along with other popular pursuits) prompted the Continental Congress to pass within its Articles of Association a recommendation that the colonists discountenance and discourage all horse racing and all kinds of gaming, cock-fighting, exhibitions of shows, plays and other expensive diversions and entertainments. Though only a 'recommendation,' American stages went dark until 1784, despite, for example, the opinion of Thomas Jefferson that:

A lively and lasting sense of filial duty is more effectually impressed on the mind of a son or daughter by reading King Lear, than by all the dry volumes of ethics, and divinity ever written. This is my idea of well-written Romance, of Tragedy, Comedy and Epic poetry. ${ }^{4}$

Many, however, still viewed the theater skeptically.

2 David Grimsted, Melodrama Unveiled, Berkeley 1987, p. 224.

3 "Be not deceived: evil communications corrupt good manners." John Milton, "Of That Sort of Dramatic Poem Which is Called Tragedy" the preface to Samson Agonistes. John Milton, John Milton, London (no date).

${ }^{4}$ Letter of Jefferson, to Robert Skipworth (August 3, 1771), Writings, Library of America, p. 742. 
As to re-writing, even Shakespeare - whose plays were a staple of American stages throughout the $18^{\text {th }}$ and $19^{\text {th }}$ centuries - was not exempt. In the late $1600 \mathrm{~s}$ authors like John Dryden and Nahum Tate, or famous actors such as Colley Cibber, altered the bard's plays to give them greater moral clarity. Romeo and Juliet, Richard III, and King Lear were 'rewritten' in order to 'purify' Juliet by not allowing Romeo to kiss her on their first date and generally to render her a more dutiful (if not altogether obedient) daughter, to emphasize more succinctly Richard's evil character in comparison to Queen Margaret's, or going to the extreme of allowing Lear and Cordelia to survive the tragedy.

William Dunlap often modified the romances and melodramas he was translating in order to appeal to American tastes. The changes were hardly subtle, even if well intended; in essence, as David Grimsted succinctly notes, "[a]ll the alterations tended toward the morally simplistic, evidenced in the heavy-handed underlining of every moral point." ${ }_{5}$ Dunlap, whose myriad translations of popular German and French plays provided a model for many of the native-authored works to follow, was only maintaining a tradition by re-writing perceived moral ambiguities.

The possibility of drama serving as a schoolroom for public edification helped to challenge those critics who only saw it as a vehicle for vice and immorality. One early superstar - and a female at that - Clara Fisher, walked a scandalous line appearing as a young boy in John Kerr's The Wandering Boys (1823) when she wore trousers revealing the line of her teenaged legs. But popular British plays like John Gay's 1728 The Beggar's Opera (the template for Bertolt Brecht's great Threepenny Opera) had many proper moral maxims, though mixed within scenes Americans thought licentiousness. Girls watching William Wycherley's The Country Wife (1672) were also being 'educated' in the ways of seduction and slander. For plays thus to have a respectable position in American society, they would have to more clearly promulgate moral virtues.

At the same time the desire to create a uniquely American expression too often resulted in the recycling of national myths that pandered more to audience taste and pocketbooks than to any intellectual exploration. William Dunlap's André (1798) used a true life event from the recent revolution for his tragedy, but when it proved a commercial flop, he re-wrote it as a musical, The Glory of Columbia: Her Yeomanry. Many versions of the Pocahontas story appeared after the first one The Indian Princess; or, La Belle Sauvage by James Nelson Barker opened in 1808. A vogue for "Indian" plays held brief sway, romanticizing the tragedy of America's indigenous peoples into a collective lament for the inevitable loss of their native lands as the tide of history and European destiny swept them away. Audiences could pity the Noble Savage while incorporating him into their own creation story. Her Christian conversion made Pocahontas

5 D. Grimsted, Melodrama, p. 21. 
a fitting heroine - plays always gave her speeches expressing gratitude for the enlightenment she has received.

Hast thou not heaven-ward turn'd my dazzled sight,

Where sing the spirits of the blessed good

Around the throne of the Holy One?

she sighs to John Rolfe in The Indian Princess, also telling him "Thou hast

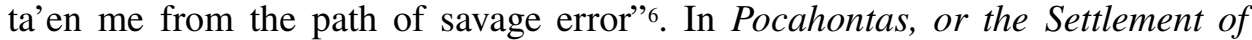
Virginia she says: "Since the light of Christian doctrine has shone on my before benighted soul, I have learn'd that mercy is one of the attributes of the divinity I now adore,"?.

Other works focusing on America's past include John Daly Burk's Bunker Hill, or the Death of General Warren (1797) or James Nelson Barker's 1824 Superstition set against the backdrop of King Philip's War. The superstar Edwin Forrest commissioned a play for himself as the lead in Metamora: the Last of the Wampanoags (1829) about Metacom/King Philip - though, as the title of the play itself reveals, historical accuracy did not even extend to granting him his true name. Mordecai Noah, one-time consul to Riga, then to the Kingdom of Tunis, until his Jewish heritage brought about his removal from office, set his comedy She Would Be a Soldier (1819) in the recently ended War of 1812. Current events (though not modern settings) were mostly ignored until Harriet Beecher Stowe in 1851 released Uncle Tom's Cabin to further divide a troubled nation over the issue of slavery. The success and notoriety of her novel ensured that numerous 'pirated' versions (at least twelve) would make their way to the stage. Another play based on Mayne Reid's popular novel The Quadroon transformed the story of a forbidden inter-racial love into The Octoroon. But Uncle Tom excepted, Americans had little interest in seeing anything but racial stereotypes presented on stage.

Finally, the preponderance of foreign-inspired romances, fairy-tale plays, and melodramas, with all their sentiment and their spectacle, provided fairly poor models for any deeper drama. William Dunlap bears a large part of the responsibility for this. A struggling theater manager, he was also a painter, playwright, and author of a "monumental work", the two-volume History of the American Theater based unfortunately more on his memories of performances rather than on accurate reporting of dates, casts, etc. but nevertheless providing through its anecdotes a fairly atmospheric recounting of the era. He wrote some 50 plays

6 Text in: Montrose J. Moses, Representative Plays by American Dramatists Vol. I 1765-1819 [after this, RPAD], New York 1918, rept. 1964, p. 611.

7 Text in: Arthur Hobson Quinn, Representative American Plays [after this, RAP], New York 1953, p. 175.

8 Moses, RPAD, p. 501. 
of all types. One early comedy The Father, or American Shadyism (1789) and the above-mentioned André (1798) are the best of his original works, but his greater influence came from his translations/adaptations from German of August von Kotzebue (a dozen or so) and Frederich Schiller, and numerous adaptations of the French fairy tale formula perfected by Guilbert de Pixérècourt to include fittingly sentimental songs and the unambiguous triumph of virtue over vice.

Kotzebue was all the rage in Europe and England; Lover's Vows, the story of a bastard son restored to his father's graces by virtue of his virtue, was used by Jane Austen as a key to character in Mansfield Park. But their fallen characters rendered them suspect. The fairy tale melodramas, though, basically transposed the black and white figures of the Cinderella story or "Beauty and the Beast" into contemporary settings. These simple morality tales increasingly featured exotic settings - Bagdad or Peru - and more spectacular special effects. Dunlap's myriad translations in effect created a template for other dramatists to copy - and Americans' love of happy endings and clear-cut good and evil characters continued to push such plots into the silent film era - and to a great extent still continues to do so. Indeed, recognized classics as disparate as Cooper's Leatherstocking Tales and Stowe's Uncle Tom's Cabin would exploit the maudlin sentiment of melodrama for thematic purposes; even Hawthorne's The Scarlet Letter highlights the pathos of ordinary people and a fundamental belief in the virtue of truth to further its point. Dunlap may well have been a mediocre writer and a financial failure, but the inadvertent influence he wielded upon American letters and culture through his legion of copycats constitutes a success of sorts.

The conclusion can be drawn, then, that the qualitative failings of early American drama, as well as its inability to create anything resembling distinguishable Art, derived from a number of influences exerting control both within and without the new nation's borders. Nevertheless, certain fruits of modern American society, nourishing both the economic and cultural spheres, were borne from this particularly barren tree.

Hollywood has long known the economic power of a well developed star system. It also knows how to exploit the market for spin-off products generated by hit series: the detritus of toys, comic books, sticker collections, coffee mugs, Halloween costumes, and whatnots that earn millions even as they become obsolete. The above mentioned Clara Fisher rose to fame in the 1820s as a young actress playing Ophelia in Hamlet, Lady Teazle in Congreve's School for Scan$d a l$, and a variety of young innocents in popular fairy tale plays of the time like Clari, the Maid of Milan. Her appearance with her sister as The Wandering Boys, a play adapted from Pixérècourt's Le Pélerin Blanc, raised eyebrows - and desires - as the two girls strutted around in pants - boys usually played girl's parts, not vice versa - but as an actress Fisher was more noted for her virtuous and vulnerable characterizations. Her fame was such that even her lisp became 
fashionable, practiced by mothers and taught to their daughters - often with visions of becoming the next Clara Fisher. Her name was "given to everything it could possibly be applied to: ships, steam-boats, race horses, mint juleps and negro babies" 9 . The introduction to her autobiography quotes a poem written as a paean to her. ${ }^{10}$ Over the century other actresses - notably Fanny Kemble or Laura Keene (one reason Abraham Lincoln was present in Ford's Theater the night Booth killed him) - would rise to prominence and remain in the public memory much longer. But Clara Fisher's popular success presaged an American penchant for superstars.

Edwin Forrest was another of the superstars of the era, known for his performances of the Shakespearean "greats" King Lear, Macbeth, and Iago; his villains, like the dastard of Thérèse, the Orphan of Geneva; and in roles specifically commissioned as vehicles for himself - as Spartacus or Metamora - both tragic figures, each a freedom fighter in his own right. Forrest's acting style might be characterized as 'American': vigorously physical and oratorically bombastic, in contrast to the restrained and cerebral 'aristocratic' style of the English. These distinctions were in no way trivial. Outside New York's Astor Place Opera House in May 1849, the conflict became murderous. American and British actors both made regular forays into 'enemy' territory. In England, Forrest received some particularly vicious reviews, probably written by friends of his rival the British star, William Macready. As revenge, he "hissed" at Macready during a performance of Hamlet by the latter. Later, in America, when they were simultaneously performing Macbeth in different theaters, some of Forrest's fans pelted Macready with coins and rotten eggs. When appearing afterwards in New York, the disruptions were more intrusive, attracting more public attention and, within two days, large crowds of supporters of each actor outside the theater, as well as the militia to control things. The Astor Place Riot resulted in some 20 deaths and Macready having a police escort as he left the theater. ${ }^{11}$ Forrest's name, like Clara Fisher's, was given to steamboats and race-horses, but also to more powerful vehicles like locomotives and fire engines.

There were others: Edwin Booth was considered America' greatest Shakespearean actor - in the intellectual English style. His father had also been a noted actor, as was his brother John (they all appeared together at least once in a production of Julius Caesar), though John's fame turned infamous when he shot Lincoln. Joseph Jefferson packed houses with his Rip van Winkle, which he was still performing nearly until his death in 1905. Anna Cora Mowatt played innocents; Charlotte Cushman was known for her terrifying, but womanly, passion.

9 Joseph Cowell, Thirty Years Passed among the Players In England and America (1844, rept. Hamden, Ct. 1979), p. 82.

10 Clara Fisher Maeder, Autobiography, New York 1897, p. xxxi.

11 For more, see Richard Moody, The Astor Place Riot, Bloomington 1958. 
All of them brought the glamour of New York, London, Paris, to stages across small town America.

Success is often a subjective measurement, of course. An opening run for an original play (i.e. not Shakespeare, etc.) might last three days, with the third performance going in larger part to the actors. Some works out-lived that span though they might find themselves performed in other cities for more three-day stints. William Dunlap, despite having authored a half-dozen plays of moderate success, turned to translation to try to sort out his financial woes. He tells us that the success of Kotzebue's The Stranger (Dunlap's first such effort) allowed his theater to keep going ${ }^{12}$. He would eventually perfect his German and do twenty translations (or adaptations from other English versions) of German works, fifteen by Kotzubue alone.

Adaptation, though, can also be a polite way of saying plagiarism. Royall Tyler's The Contrast was modeled on School for Scandal which he had seen just three weeks earlier. Dunlap 'adapted' The Italian Father (1810) from Thomas Dekker's The Honest Whore; twenty years later it appeared as The Deformed (1830) by Richard Penn Smith, taking bits from both Dekker and Dunlap. Thus, by mid-century there was nothing unusual in Dion Boucicault rewriting the melodrama Les Pauvres de Paris (1856), a great hit for its French authors, to become (in its American incarnations) The Poor of New York and The Streets of Philadelphia, and elsewhere, depending on the city, The Poor of Liverpool, The Streets of Dublin and The Streets of London. The latter title was used because The Real Poor of London had already been appropriated as a title for a different author's pirated version of the play. Whatever worked was fair game for a budding author.

When in 1855 the notorious New York gang leader Bill "the Butcher" Poole (boss of the "Native Americans," a strong-arm spin-off of the extreme nationalist Know-Nothing party) lay dying of bullet wounds in a bar after being 'hit' by an opposing gang, he gasped out, "Goodbye, boys; I die a true American!" In a Roaring Twenties-era history of New York gangs, Herbert Asbury chronicles that:

For weeks little was discussed throughout the city but the murder of Butcher Bill and the magnificence of his funeral, and the last words of the famous gangster were widely quoted. New plays were hurriedly written for the cheaper theaters which specialized in melodrama, and the endings of current productions were changed, so that as the final curtain fell the hero could drape himself in an American flag and gasp hoarsely, "Goodbye, boys; I die a true American!" while the audience expressed its emotion in thunderous applause. ${ }^{13}$

12 William Dunlap, History of the American Theater, London 1833, vol. II, p. 81.

${ }^{13}$ Herbert Asbury, The Gangs of New York: An Informal History of the Underworld, New York 1928, p. 90. 
It is no surprise, then, that within a year of its publication the immensely popular Uncle Tom's Cabin (1851) had already made its way to the stage in various versions tailor-made for their Northern or Southern audiences. Sitting in the crowd and cribbing the laugh lines or sketching out an effective dramatic confrontation was a precursor to today's film pirates, recording new releases on their cellphones - though in the 1800s more profit was involved. (This also helps explain why many plays never made it beyond their manuscripts or even director's notes: authors didn't want to make copying any easier.) Do multiple variations - or variations of variations - of a product represent a type of success?

There were, however, box-office successes as well. Anna Cora Mowatt's 1845 hit Fashion, or Life in New York ran for three weeks to full houses - remember, three days was a decent run - and only stopped due to actors' obligations elsewhere. ${ }^{14}$ It moved to Philadelphia with a different cast and continued its success. Through 1850 it was regularly staged - often with Mowatt herself in the role of good-daughter Gertrude. The Broadway Journal on March 29, 1845 published a long mostly critical review by Edgar Allan Poe, who wrote a second more favorable one a week later which noted that he'd seen performances daily since his first review! Later, he would also condemn the negative attitude toward the stage still prevalent in many segments of society. Both Mowatt's play and her fame as an actress (typically, as the 'good daughter' so prevalent in most plays of the era) took her on a critically acclaimed ${ }^{15}$ European tour as well, where she gained praise for her restrained, un- 'American' style of acting. Fashion would be successfully revived in the $1920 \mathrm{~s}$

Fashion's box-office success would be far surpassed by that of Uncle Tom's Cabin. Not just the topicality of slavery, intensified by the recent introduction of the Fugitive Slave Act, but the story itself struck a chord. After all, the travails of saintly Uncle Tom and angelic Little Eva, the nobility of mulatto George, the sinfulness of slave-owner Simon Legree: what were these but recognizable manifestations of the numerous fairy-tale figures nightly acting out their own dramas on stages across America? The popularity and notoriety of Stowe's book resulted in numerous unauthorized theatrical productions penned by different authors. The showman P.T. Barnum, already involved with George Aiken's version, produced another by Henry J. Conway in a neighboring local theater, leading to riots between rival fans as to which version was superior. ${ }^{16}$ The work spawned collateral products as promiscuously as do modern blockbusters like the Star Wars or Harry Potter series:

14 Anna Cora Mowatt, Autobiography of an Actress, Boston 1854, p. 210.

15 A. C. Mowatt, Autobiography, pp. 271, 284.

16 Bruce McConachie, Melodramatic Formations, Iowa City 1992, p. 178. 
... immediately produc[ing] a flood of imitative drama, poetry, and songs that capitalized upon its most saccharine scenes. The melodramatic apotheosis of Eva and bowdlerized scenes of minstrel humor appeared in consumable artifacts - dioramas, engravings, gift books, card games, figurines, plates, silverware, and needlepoint. ${ }^{17}$

The Aiken version ended with "the most famous tableau [a frozen, wordless picture] in all of American drama"18:

Gorgeous clouds, tinted with sunlight. Eva, robed in white, is discovered on the back of a milk-white dove, with expanded wings, as if just soaring upwards. Her hands are extended in benediction over St. Clare and Uncle Tom who are kneeling and gazing up to her. Expressive music. Slow curtain.

$\mathrm{END}^{19}$

Treacle it might have been, serving up song, tears, and flat characters with crowdpleasing effects, but as with Fashion it struck a chord well into the twentieth century. The immense popularity of the play is best documented by an unattributed column from 1933 noting the uninterrupted run of various Uncle Tom productions in New York City from Summer 1853 until 193020.

In one important respect, though, the collective body of American melodrama allowed the public to share in, and by its approbation shape, the development of a pro-American, pro-patriotic ethos which would come to consistently underlie the sentiments of good stage characters of whatever class. Certain playwrights, like William Dunlap, James Nelson Barker, and Mordecai Noah, wrote of their desire - even sense of mission - to create an American canon, or as Noah himself would write, a "hankering for the national drama." ${ }^{21}$ One primary idea shared and voiced by all good characters concerned the connection between individual virtue and love of country. In works of the immediate post-revolutionary period, sacrifice and duty as essential components of patriotism are pre-eminent among the ideals expressed.

Hugh Henry Brackenridge's The Battle of Bunkers-Hill (1776) "the first American play popular enough to receive repeated performances in many cities" 22 , is an early demonstration of the public's desire for patriotic fare. And though it would take until the Jacksonian era for American nationalism to become a tangible force, most works - even those with no American setting whatsoever

17 Eric J. Sundquist, ed. New Essays on Uncle Tom's Cabin, New York 1999, p. 4.

18 Text in: Daniel C. Gerould, American Melodrama, [after this, AM], New York City 1983, p. 17.

19 Text of Uncle Tom from Gerould, AM, p. 133.

20 Talk of the Town "The New Yorker", July 11933.

21 From a letter to William Dunlap dated July 11 1832, reprinted by Dunlap, History.

22 Grimsted, Melodrama, p. 76. 
- had characters intoning axioms extolling individual freedom, the greatness of the land and other sentiments.

The venue itself was patriotic spectacle. Theaters often doubled as public meeting halls and as a result had flags framing the stage, stars-and-stripes motif bunting and/or curtains, images of bald eagles, and in the case of Philadelphia's Walnut Street Theatre, sometimes much more:

Each tier of boxes was decorated with paintings representing some celebrated battle in the history of the United States. Around the dress circle were placed medallions of the heads of the presidents. Around the second tier, the heads of celebrated generals; and around the third, the heads of naval heroes. Between each medallion was a large burnished gold star...23

One reason for Edwin Forrest's great appeal was his fervent patriotism. His great characters Metamora and Spartacus declaimed on liberty and country, freedom and justice - all traits Americans associated with their own nation. The first major historian of the early American stage, Montrose J. Moses, recounts Forrest literally kissing an American flag ${ }^{24}$ before audiences. In a land where even a dying mob-boss's last words were patriotic sentiments, perhaps this should not be surprising.

Almost while the ink on the new Constitution was still drying, Royall Tyler's Prologue to The Contrast derides European grace and hypocrisy by praising American directness ("Our free-born ancestors such arts despis'd; / Genuine sincerity alone they priz'd"). The play's hero, Colonel Manly, frequently discourses on American virtue while the play's heroine Maria extols the importance of serving one's country. In Mordecai Noah's 1819 preface to his She Would Be a Soldier, he remarks that "[Americans] have a fine scope, and abundant material to work with, and a noble country"25. William Dunlap gives General Washington - in 1798 a nearly god-like figure of veneration - numerous opportunities to wax poetic on America:

O patriotism!

Thou wondrous principle of godlike action.

Wherever liberty is found, there reigns

The love of country. ${ }^{26}$

${ }^{23}$ Francis Weymiss, Twenty-Six Years of the Life of an Actor and Manager, 2 Vol., New York 1847 , v. 2, pp. 234-5.

${ }^{24}$ Montrose J. Moses, The Fabulous Forrest: The Record of an American Actor, Boston 1929, p. 124.

25 Preface reprinted in: Moses, RPAD, p. 641.

26 Washington and Seward converse, RPAD, p. 519. 
But it is not just George Washington intoning such ideas. Indians, too, often voice their belief in the American land as being the finest on earth:

...amid all the splendours of the courts of Europe, I have never forgot my native land, but long'd to re-visit even in poverty and nothingness; while amid the pomp and pageantry of England, I sighed for the sports of our rude forests, and the wild, free life of an Indian. I wish'd to be away from the restraints of civiliz'd society, to throw off the cumbrous dress which fetter'd my limbs, and re-assume my nakedness and liberty; to enjoy the hunt and the dance, and again to become a son of Virginia. ${ }^{27}$

Forrest's Metamora shouts out "Our lands! Our nation's freedom! Or the grave!" 28 And even in Francesca da Rimini (1855) George Boker's ambitious five-act verse tragedy set in $13^{\text {th }}$ century Italy, there is room for the Fool Pepé to envision a place strongly resembling the audience's vision of America:

I'd have no families, no [Noble class],

Strutting about the land with pedigrees....

I'd have [people] spring, like toadstools, from the soil -

Mere sons of women - nothing more nor less -

All base-born, and all equal. There my lord,

There is a simple commonwealth for you!

In which aspiring merit takes the lead,

And birth goes begging. ${ }^{29}$

In fact, such comments provide a ubiquitous subtext to plays of all stripes, comedies, tragedies, melodramas, and spring from the mouths of heroes, good daughters, servants, even Indian characters. Royall Tyler's American setting for The Contrast (1787) gives him reason to announce at the beginning: "Exult each patriot heart!:

Our author pictures not from foreign climes

The fashions, or the follies of the times;

But has confin'd the subject of his work

To the gay scenes - the circles of New York.

On native themes his Muse displays her pow'rs;

If ours the fault, the virtues too are ours.

Why should our thoughts to distant countries roam,

When each refinement may be found at home? ${ }^{30}$

27 RAP, p. 176.

28 Text in: William Coyle and Harvey Damaser, ed. Six Early American Plays: 1798-1890 [after this SEAP], Columbus Ohio 1965, p. 89.

29 Text in: Myron Matlaw, Ed. The Black Crook and Other Nineteenth-Century American Plays, New York 1967, p. 145.

30 RPAD, p. 444. 
His servant character Jonathan, would become a model for a recurring "Yankee" type: plainspoken, commonsensical, humorous, smart, and shrewd despite - or the result of! - his rustic origins. At one point, Jonathan, amidst all his sage silliness, sings one of the most recognizable American songs of the time, "Yankee Doodle" - a certifiable crowd-pleaser. ${ }^{31}$ When he mentions that he knows it, the servant Jenny coos, "Oh! it is the tune I am fond of: and if I know anything of my mistress, she would be glad to dance to it."

As time progressed, the Yankee figure would move from a subordinate role to become the hero. Fashion's Adam Trueman is hardly on-stage when he rejoices, "Hurrah for republican simplicity.!" To the French villain, he threatens, "I'll teach you the way we natives joke with a puppy who don't respect an honest woman!" after earlier informing him "I belong to a land in which I rejoice to find you a foreigner." ${ }_{22}$ 'We natives' were reminded nightly on stages around the country of their "great, yet virtuous empire in the West!" ${ }_{33}$ as John Smith orates at the end of The Indian Princess (1808) Even the embittered mulatto George from Uncle Tom's Cabin echoes Patrick Henry's speech to the Virginia convention as he cries "I'll be free - or die!" ${ }_{34}$ The stage Yankee or his surrogates intoned the truths American audiences both desired and demanded.

Though battles had initially been fought over the stage's propriety, and though the general quality of the product can hardly be considered as meeting the "gold" standard, there can be little argument or doubt as to American theater's force as a socializing institution. Its influence was pervasive: an audience existed whose appetite for thrill easily coexisted with a desire for instruction. From out the chaff - despite the chaff! - the entertainment industry reaped gold from its efforts: financial success for the few maybe, but the alchemy succeeded in transforming and establishing the values of a nascent society.

\section{Wczesne amerykańskie hity sceniczne: Od nicości do wartości}

Wczesny dramat amerykański był nieodmiennie słabej jakości. Z około 700 sztuk napisanych przez rodzimych autorów pomiędzy 1776 a wojną secesyjną, przetrwało mniej niż dziesięć procent. Jednak, sztuki te oddziaływały na wiele sposobów: niektóre okazały się sukcesem finansowym - ich popularność przyczyniła się do rozbudowania „systemu gwiazdorskiego” oraz stałego ulepszania

\footnotetext{
31 This would not be the only time "Yankee Doodle" made its way on stage; William Dunlap would include it in his rewritten musical version of André, the popular The Glory of Columbia Her Yeomanry (1817), which would make the theatrical rounds for years.

32 SEAP, pp. 122, 116.

33 RPAD, p. 627.

34 SEAP, p. 78.
} 
efektów specjalnych - obie te cechy nadal charakteryzują Hollywood i przemysł rozrywkowy. Jednak, istotniejsze wydaje się to, że ich tematyka i treść przyczyniły się do wykształcenia poczucia patriotyzmu, przynależności narodowej i wspólnych wartości. Sukces w budowaniu nowego społeczeństwa jednoznacznie przewyższa ich wartość literacką.

Słowa kluczowe: wczesny dramat amerykański, dziewiętnastowieczne amerykańskie wartości społeczne, historia teatru amerykańskiego 